\title{
Case Report: A case report of Moyamoya disease in a 36 year old African American woman [version 1; peer review: 2
}

\section{approved]}

\section{Rohit Kumar Gudepu1, Mohtashim A. Qureshi², Ihtesham A. Qureshi², Lakshman Rao'}

${ }^{1}$ Dunnerwin Medical Center, Dunn, North Carolina, USA

${ }^{2}$ Mamata Medical College, Khammam, Telangana, India

\begin{tabular}{l} 
V1 First published: 08 Dec 2014, 3:297 \\
https://doi.org/10.12688/f1000research.5859.1 \\
Latest published: 08 Dec 2014, 3:297 \\
https://doi.org/10.12688/f1000research.5859.1 \\
\hline
\end{tabular}

\section{Abstract}

Moyamoya is a rare idiopathic progressive vaso-occlusive disease characterized by irreversible condition of main blood vessels to the brain as they enter into the skull. We present a case of 36 year old African American female presenting to the Out Patient Clinic with headache which were on and off for 4-6 months and did not relieve on routine medical therapy. It was associated with weakness on right side for last few days. The patient was investigated with CT Angiogram, diagnosed as Moyamoya disease and operated. She has been followed up for the last 5 years and the patient has not complained of any headaches or focal neurological symptoms.

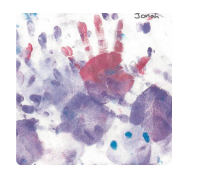

This article is included in the Rare diseases collection.

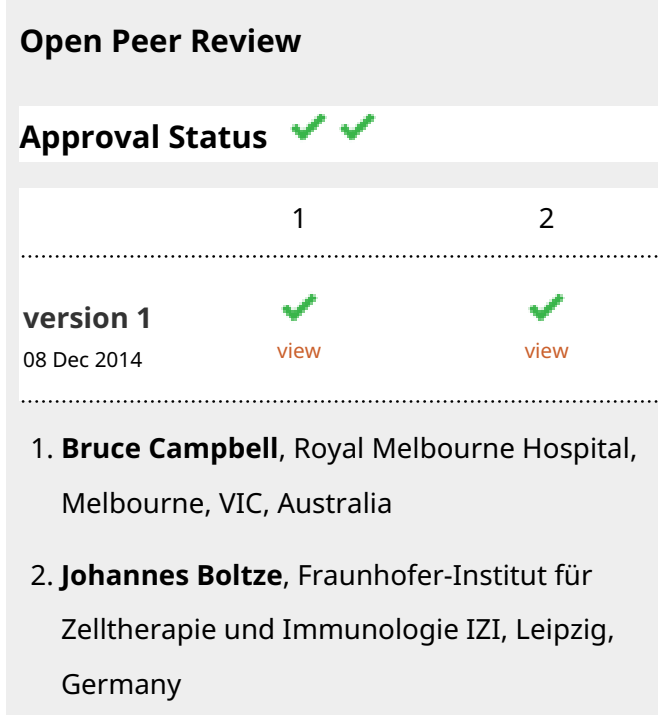

Any reports and responses or comments on the article can be found at the end of the article.

Corresponding author: Rohit Kumar Gudepu (rohitgudepu@gmail.com)

Competing interests: No competing interests were disclosed.

Grant information: The author(s) declared that no grants were involved in supporting this work.

Copyright: $\odot 2014$ Gudepu RK et al. This is an open access article distributed under the terms of the Creative Commons Attribution License, which permits unrestricted use, distribution, and reproduction in any medium, provided the original work is properly cited. Data associated with the article are available under the terms of the Creative Commons Zero "No rights reserved" data waiver (CC0 1.0 Public domain dedication).

How to cite this article: Gudepu RK, Qureshi MA, Qureshi IA and Rao L. Case Report: A case report of Moyamoya disease in a 36 year old African American woman [version 1; peer review: 2 approved] F1000Research 2014, 3:297

https://doi.org/10.12688/f1000research.5859.1

First published: 08 Dec 2014, 3:297 https://doi.org/10.12688/f1000research.5859.1 


\section{Introduction}

Moyamoya disease is a progressive occlusive condition involving cerebral vessels which includes mainly, stenosis of distal internal carotid arteries on both sides and anterior and middle cerebral arteries thereby leading to development of collateral vessels to compensate for the occlusion. Moyamoya is a rare disease with reported incidence of 0.086 per 100,000 population ${ }^{1}$. Though, originally considered to affect predominantly persons of Asian heritage it is now seen throughout the world in people of many ethnic backgrounds ${ }^{2,3}$. There are nearly twice as many female patients as male patients ${ }^{4,9,10}$. Moyamoya disease usually is associated with condition like Sickle cell disease, Down's Syndrome and Neurofibromatosis- $1^{4-7}$.

\section{Case description}

A 36 year old African American female presented to the Out Patient Office with headache which was on and off for last 4-6 months. The headache presented was of piercing type with moderate intensity not relieved by butalbital, acetaminophen. It was associated with weakness on right hand side for last few days, which evolved into dizziness and speech difficulty. There was no associated fever, night sweats, loss of consciousness, vomiting, ataxia, photophobia, tingling, numbness, difficulty swallowing, difficulty hearing, neck stiffness, vision problems. Her family history was significant for hypertension, diabetes and coronary artery disease. General physical examination showed no abnormalities. She is obese with BMI of 36.4; Vitals include [Heart Rate $=93 / \mathrm{min}$, Blood Pressure $=165 / 75 \mathrm{~mm} \mathrm{Hg}$, Temp. $=36 \cdot 67^{\circ} \mathrm{C}$, Resp. Rate $\left.=18 / \mathrm{min}\right]$. Neurological examination showed intact 2-12 cranial nerve function, motor strength grossly intact with strength $3 / 5$ on the right side of hand. No pronator drift, normal muscular tone, and gait was normal. Laboratory investigations, complete blood count, electroencephalogram and echocardiogram were normal.

A CT angiogram head with contrast shows one sagittal [Figure 1] and two axial views [Figure 2, Figure 3] at the level of the lateral ventricle and Circle of Willis, demonstrate mild proliferation of

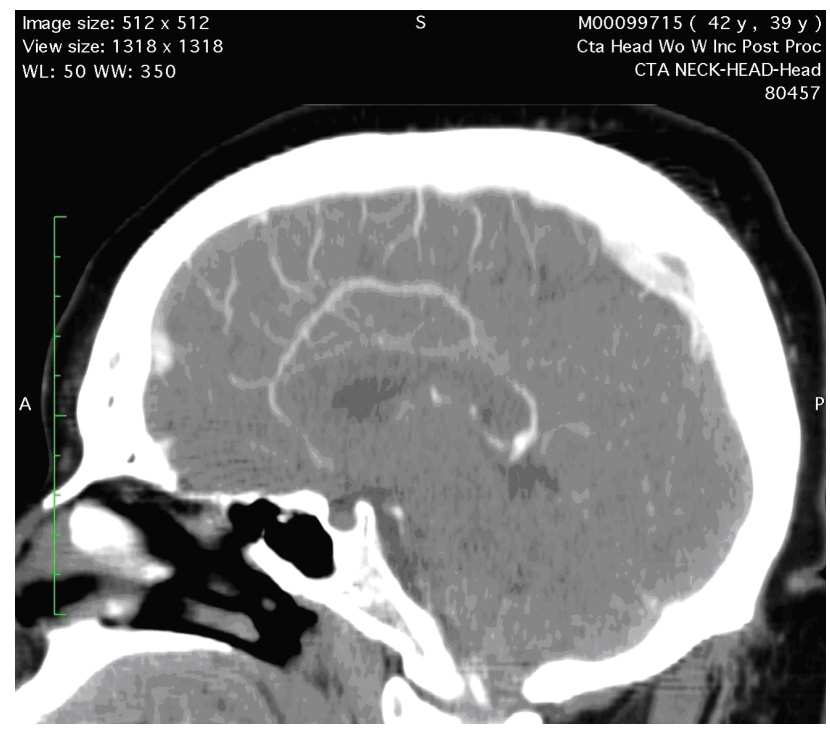

Figure 1. Sagittal view of a CT Angiogram of the head at the level of lateral ventricle demonstrates mild proliferation of the collateral vessels extending towards the vertex.

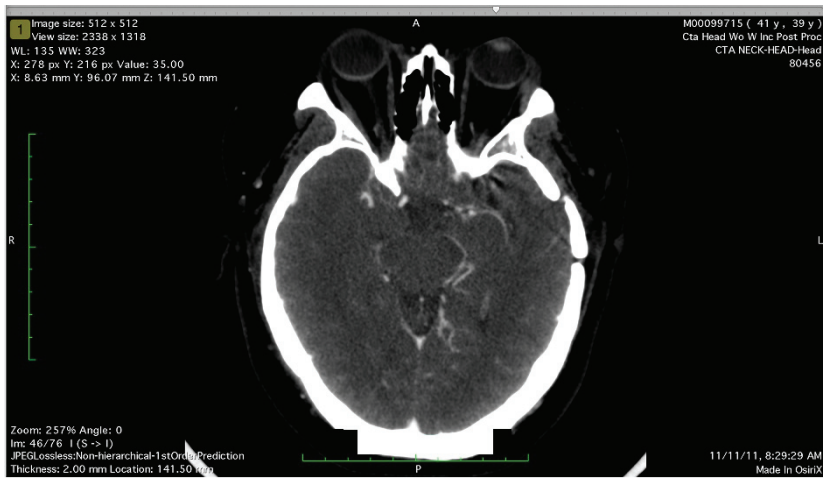

Figure 2. Axial view of CT Angiogram of the head at the level of the Circle of Willis demonstrates mild proliferation of collateral vessels emanating from the distal internal carotid artery, particularly on the left side. In addition, the visualized portion of the distal internal carotid artery and M1 segment of the left middle cerebral artery appear somewhat diminutive in caliber.

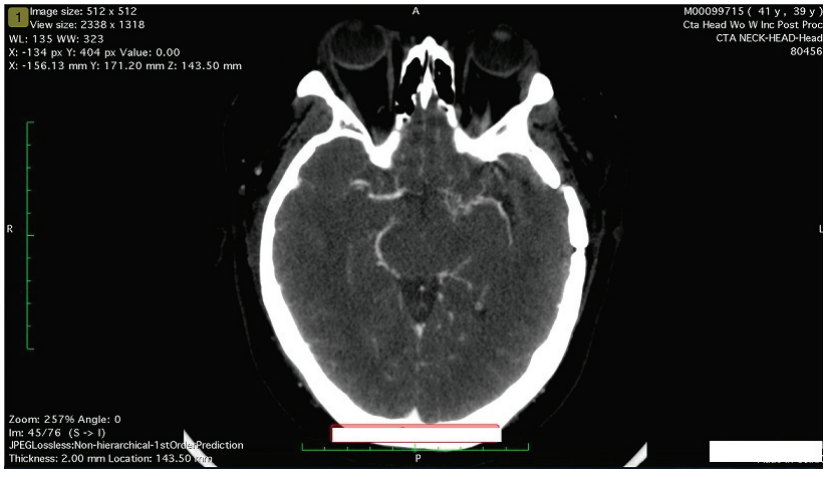

Figure 3. Axial view of CT Angiogram of the head at the level of the Circle of Willis demonstrates mild proliferation of collateral vessels emanating from the distal internal carotid artery, particularly on the left side. In addition, the visualized portion of the distal internal carotid artery and M1 segment of the left middle cerebral artery appear somewhat diminutive in caliber.

collateral vessels emanating from the distal internal carotid artery particularly on the left side. In addition, the visualized portion of the distal internal carotid artery and M1 segment of the left middle cerebral arteries appeared somewhat diminutive in caliber. Findings were generally compatible with progressive vascular occlusive process which can be seen in Moyamoya disease.

Since the patient was refractory to the pain medications, surgical revascularization was done and the procedure involved left superficial temporal artery-left middle cerebral artery bypass without any complications. Following surgery, she was prescribed $81 \mathrm{mg}$ aspirin and discharged home and was followed up initially after surgery once every three months for one year followed by every 6 months for next four years. She did not complain of any headaches or focal neurological symptoms.

\section{Discussion}

Moyamoya disease is a chronic, progressive occlusion of the Circle of Willis arteries that leads to the development of characteristic collateral vessels seen on imaging, particularly cerebral angiography ${ }^{8}$. 
Moyamoya was originally considered to affect predominantly persons of Asian heritage but has now been observed throughout the world. The incidence peaks lie within two age groups: children who are 5 years old and adults in their mid 40's $\mathrm{s}^{9-12}$. Moyamoya disease is rarely seen in the African American population. Uchino et al. ${ }^{1}$ found only 27 African Americans with Moyamoya disease in the states of California and Washington. According to the year 2000 US Census population, only 44 African Americans were diagnosed with Moyamoya every year ${ }^{8}$.

Moyamoya usually presents with recurrent headaches and is migraine like in quality and refractory to medical therapies. Being a chronic progressive occlusive condition it causes stenosis of intracranial internal carotid arteries and their proximal branches causing reduced blood supply to the anterior surface of brain, thereby leading to the formation of collaterals near the apex of carotids which look like "Puffs of Smoke" known as Moyamoya in Japanese ${ }^{13}$. The process of blockage, once it begins, tends to continue despite any known medical management unless treated with surgery ${ }^{14}$.

Though MRI angiography is used to confirm the diagnosis and to see the anatomy of the vessels involved, CT angiography can also be used to see intracranial stenoses suggesting Moyamoya. Thus, CT angiography can be considered when MRI is not readily available and a diagnosis of cerebral occlusive vasculopathy is being considered $^{15}$. Since surgery is the only viable option, revasularization procedures are gaining importance as a primary treatment for Moyamoya, given the poor response to medical therapy and documented success of surgery ${ }^{17}$.

A good option for adult symptomatic patients is superficial temporal artery-middle cerebral artery bypass or middle meningeal artery to middle cerebral artery bypass ${ }^{18-21}$. Patients have reported to have $96 \%$ probability of remaining stroke free over the subsequent five years $^{4,16}$. The present patient had a successful surgical treatment without any recurrence of symptoms. Nevertheless, the outcome can be predicted based on the neurological status at the time of treatment, more than the patient's age ${ }^{4}$. Hence, it is necessary for early diagnosis of the condition followed by surgical intervention therapy. The estimated rate of symptomatic progression is only $2.6 \%$ after surgery according to a meta-analysis involving 1156 patients $^{17}$.

This case highlights the importance of considering Moyamoya disease as one of the differentials while dealing with patients with recurrent headaches who are in their third/fourth decade of life and children around 5 years old in whom headache is not relieved on routine medical treatment. It also emphasizes on the rare presentation among African American population and use of CT angiography as an alternative diagnostic imaging tool for diagnosing Moyamoya in cases of MRI non-availability.

\section{Patient consent}

Informed written consent for publication of clinical details was obtained from the patient.

\section{Author contributions}

RG, MQ, IQ have performed literature review and manuscript writing. LR helped to make the diagnosis. All the authors approved the final version of the manuscript.

\section{Competing interests}

No competing interests were disclosed.

\section{Grant information}

The author(s) declared that no grants were involved in supporting this work.
1. Uchino K, Johnston SC, Becker KJ, et al.: Moyamoya disease in Washington State and California. Neurology. 2005; 65(6): 956-8.

PubMed Abstract | Publisher Full Text

2. Caldarelli M, Di Rocco C, Gaglini P: Surgical treatment of moyamoya disease in pediatric age. J Neurosurg Sci. 2001; 45(2): 83-91. PubMed Abstract

3. Suzuki J, Kodama N: Moyamoya disease--a review. Stroke. 1983; 14(1): 104-9. PubMed Abstract | Publisher Full Text

4. Scott RM, Smith JL, Robertson RL, et al.: Long-term outcome in children with moyamoya syndrome after cranial revascularization by pial synangiosis. J Neurosurg. 2004; 100(2 Suppl Pediatrics): 142-9. PubMed Abstract | Publisher Full Text

5. Jea A, Smith ER, Robertson R, et al:: Moyamoya syndrome associated with Down syndrom: outcome after surgical revascularization. Pediatrics. 2005; 116(5): e694-e701.

PubMed Abstract | Publisher Full Text

6. Hankinson TC, Bohman LE, Heyer G, et al.: Surgical treatment of moyamoya syndrome in patients with sickle cell anemia: outcome following encephaloduroarteriosynangiosis. J Neurosurg Pediatr. 2008; 1(3): 211-6. PubMed Abstract | Publisher Full Text

7. Ullrich NJ, Robertson R, Kinnamon DD, et al:: Moyamoya following cranial irradiation for primary brain tumors in children. Neurology. 2007; 68(12): 932-8. PubMed Abstract | Publisher Full Text

8. Janda PH, Bellew JG, Veerappan V: Moyamoya disease: case report and literature review. J Am Osteopath Assoc. 2009; 109(10): 547-53. PubMed Abstract

9. Baba T, Houkin K, Kuroda S: Novel epidemiological features of moyamoya disease. J Neurol Neurosurg Psychiatry. 2008; 79(8): 900-4. PubMed Abstract | Publisher Full Text

10. Wakai K, Tamakoshi A, Ikezaki K, et al.: Epidemiological features of moyamoya disease in Japan: findings from a nationwide survey. Clin Neurol Neurosurg. 1997; 9(Suppl 2): S1-S5.

PubMed Abstract | Publisher Full Text

11. Han $\mathrm{DH}, \mathrm{Nam} \mathrm{DH}, \mathrm{Oh} \mathrm{CW}$ : Moyamoya disease in adults: characteristics of clinical presentation and outcome after encephalo-duro-arterio-synangiosis. Clin Neurol Neurosurg. 1997; 99(Suppl 2): S151-S155. PubMed Abstract | Publisher Full Text

12. Han $\mathrm{DH}$, Kwon $\mathrm{OK}$, Byun $\mathrm{BJ}$, et al: A co-operative study: clinical characteristics of 334 Korean patients with moyamoya disease treated at neurosurgical institutes (1976-1994). The Korean Society for Cerebrovascular Disease. Acta Neurochir (Wien). 2000; 142(11): 1263-73. PubMed Abstract | Publisher Full Text

13. Fukui M: Guidelines for the diagnosis and treatment of spontaneous occlusion of the circle of Willis ('moyamoya' disease). Research Committee on Spontaneous Occlusion of the Circle of Willis (Moyamoya Disease) of the Ministry of Health and Welfare, Japan. Clin Neurol Neurosurg. 1997: 99(Suppl 2): S238-S240.

PubMed Abstract | Publisher Full Text 
14. Smith ER, Smith RM: "Moyamoya syndrome associated with Congenital heart diseases". Skull Base. 2005; 15(1): 15-26.

15. Scott RM, Smith ER: "Moyamoya disease and moyamoya syndrome". N Eng J Med. 2009; 360(12): 1226-37.

PubMed Abstract | Publisher Full Text

16. Choi JU, Kim DS, Kim EY, et al:: Natural history of moyamoya disease: comparison of activity of daily living in surgery and non surgery groups. Clin Neurol Neurosurg. 1997; 99(Suppl 2): S11-S18. PubMed Abstract | Publisher Full Text

17. Fung LW, Thompson D, Ganesan V: Revascularization surgery for pediatric moyamoya: a review of the literature. Childs Nerv Syst. 2005; 21(5): 358-64. PubMed Abstract | Publisher Full Text

18. Kuroda S, Ishikawa $\mathrm{T}$, Houkin $\mathrm{K}$, et al.: Incidence and clinical features of disease progression in adult moyamoya disease. Stroke. 2005; 36(10): 2148-2153. PubMed Abstract | Publisher Full Text

19. Oya S, Tsutsumi K, Ueki K: Adult-onset moyamoya disease with repetitive ischemic attacks successfully treated by superficial temporal-middle cerebral artery bypass--case report. Neurol Med Chir (Tokyo). 2003; 43(3): 138-141. PubMed Abstract | Publisher Full Text

20. Golby AJ, Marks MP, Thompson RC, et al.: Direct and combined revascularization in pediatric moyamoya disease. Neurosurgery. 1999; 45(1): 50-58.

PubMed Abstract

21. Imama $\mathrm{T}$, Hashimoto $\mathrm{N}$, Miyaka $\mathrm{H}$, et al.: Direct revascualrization to the anterior cerebral artery territory in patients with moyamoya disease: report of five cases. Neurosurgery. 1998; 42(5): 1157-1161.

PubMed Abstract | Publisher Full Text 


\section{Open Peer Review}

\section{Current Peer Review Status:}

\section{Version 1}

Reviewer Report 16 February 2015

https://doi.org/10.5256/f1000research.6261.r7591

(C) 2015 Boltze J. This is an open access peer review report distributed under the terms of the Creative Commons Attribution License, which permits unrestricted use, distribution, and reproduction in any medium, provided the original work is properly cited.

\section{Johannes Boltze \\ Department of Cell Therapies, Fraunhofer-Institut für Zelltherapie und Immunologie IZI, Leipzig, Germany}

This manuscript delivers a comprehensive, well-structured and interesting case study on MoyaMoya. The paper is nicely focused and compact, also providing a well-balanced discussion.

Apart from agreeing on Dr. Campell's comment, the only recommendation I have is to avoid repetitive text elements. Particularly, the first few sentences in the second paragraph of the case description are almost identical to the legend of Figure 2 and may therefore require rephrasing.

Competing Interests: No competing interests were disclosed.

I confirm that I have read this submission and believe that I have an appropriate level of expertise to confirm that it is of an acceptable scientific standard.

Reviewer Report 16 December 2014

https://doi.org/10.5256/f1000research.6261.r6982

(C) 2014 Campbell B. This is an open access peer review report distributed under the terms of the Creative Commons Attribution License, which permits unrestricted use, distribution, and reproduction in any medium, provided the original work is properly cited.

\section{Bruce Campbell}

Department of Neurology, Royal Melbourne Hospital, Melbourne, VIC, Australia

An interesting rare disease case report - NB in Intro states "Moyamoya disease usually is associated with condition like Sickle cell disease, Down's Syndrome and Neurofibromatosis" -whilst 
all of these associations are correct, the majority of Moyamoya patients do not have one of these conditions.

Competing Interests: No competing interests were disclosed.

I confirm that I have read this submission and believe that I have an appropriate level of expertise to confirm that it is of an acceptable scientific standard.

The benefits of publishing with F1000Research:

- Your article is published within days, with no editorial bias

- You can publish traditional articles, null/negative results, case reports, data notes and more

- The peer review process is transparent and collaborative

- Your article is indexed in PubMed after passing peer review

- Dedicated customer support at every stage

For pre-submission enquiries, contact research@f1000.com 